\title{
Potential climate change impacts on temperate forest ecosystem processes
}

Emily B. Peters, Kirk R. Wythers, Shuxia Zhang, John B. Bradford, and Peter B. Reich

\begin{abstract}
Large changes in atmospheric $\mathrm{CO}_{2}$, temperature, and precipitation are predicted by 2100, yet the long-term consequences for carbon $(\mathrm{C})$, water, and nitrogen $(\mathrm{N})$ cycling in forests are poorly understood. We applied the PnET-CN ecosystem model to compare the long-term effects of changing climate and atmospheric $\mathrm{CO}_{2}$ on productivity, evapotranspiration, runoff, and net nitrogen mineralization in current Great Lakes forest types. We used two statistically downscaled climate projections, PCM B1 (warmer and wetter) and GFDL A1FI (hotter and drier), to represent two potential future climate and atmospheric $\mathrm{CO}_{2}$ scenarios. To separate the effects of climate and $\mathrm{CO}_{2}$, we ran PnET-CN including and excluding the $\mathrm{CO}_{2}$ routine. Our results suggest that, with rising $\mathrm{CO}_{2}$ and without changes in forest type, average regional productivity could increase from $67 \%$ to $142 \%$, changes in evapotranspiration could range from $-3 \%$ to $+6 \%$, runoff could increase from $2 \%$ to $22 \%$, and net $\mathrm{N}$ mineralization could increase $10 \%$ to $12 \%$. Ecosystem responses varied geographically and by forest type. Increased productivity was almost entirely driven by $\mathrm{CO}_{2}$ fertilization effects, rather than by temperature or precipitation (model runs holding $\mathrm{CO}_{2}$ constant showed stable or declining productivity). The relative importance of edaphic and climatic spatial drivers of productivity varied over time, suggesting that productivity in Great Lakes forests may switch from being temperature- to water-limited by the end of the century.
\end{abstract}

Résumé : On prévoit que le $\mathrm{CO}_{2}$ atmosphérique, la température et la précipitation auront subi d'importants changements vers 2100 mais notre compréhension des conséquences à long terme sur le recyclage du carbone $(\mathrm{C})$, de l'eau et de l'azote $(\mathrm{N})$ est déficiente. Nous avons appliqué le modèle d'écosystème PnET-CN pour comprendre les effets à long terme du changement climatique sur la productivité, l'évapotranspiration, le ruissellement et la minéralisation nette de $\mathrm{N}$ dans les divers types actuels de forêt des Grands Lacs. Nous avons utilisé deux projections du climat à échelle statistiquement réduite : PCM B1 (plus chaud et plus humide) et GFDL A1FI (plus chaud et plus sec) représentatives de deux scénarios futurs potentiels du climat et du $\mathrm{CO}_{2}$ atmosphérique. Nous avons exécuté PnET-CN en incluant ou non la routine pour le $\mathrm{CO}_{2}$ pour distinguer les effets du climat de ceux du $\mathrm{CO}_{2}$. Avec une augmentation du $\mathrm{CO}_{2}$ et sans que le type de forêt change, nos résultats indiquent que : la productivité régionale moyenne pourrait augmenter de $67 \%$ à $142 \%$, les changements dans l'évapotranspiration pourraient varier de $-3 \%$ à $+6 \%$, le ruissellement pourrait augmenter de $2 \%$ à $22 \%$ et la minéralisation nette de $\mathrm{N}$ pourrait augmenter de $10 \%$ à $12 \%$. Les réactions de l'écosystème variaient selon les caractéristiques géographiques et le type de forêt. L'augmentation de la productivité était presque entièrement due aux effets de fertilisation $\mathrm{du} \mathrm{CO}_{2}$ plutôt qu'à la température ou à la précipitation (les passages du modèle en gardant le $\mathrm{CO}_{2}$ constant prédisaient une productivité stable ou décroissante). L'importance relative des facteurs spatiaux édaphiques et climatiques de productivité variaient avec le temps indiquant que la productivité des forêts des Grands Lacs qui est aujourd'hui limitée par la température pourrait être limitée par la précipitation vers la fin du siècle. [Traduit par la Rédaction]

\section{Introduction}

Recent changes in global and regional climate are now welldocumented and generally show an increase in mean annual temperature, more extreme hot days, and more episodic and intense precipitation events (Solomon et al. 2007; Karl et al. 2009; Hansen et al. 2012). While these trends are expected to continue into the future, the exact magnitude of change is highly uncertain (Solomon et al. 2007). For example, by 2100 global mean temperature is projected to rise by $1.4{ }^{\circ} \mathrm{C}$ to $5.8^{\circ} \mathrm{C}$, depending in part on the quantity of future greenhouse gas emissions. The resilience of ecosystems to these current and projected changes in climate is of great concern, as humans rely on a multitude of services provided by healthy functioning ecosystems.

Forest ecosystems, in particular, represent 30\% of the world's land surface and provide a suite of services, including timber products, clean water, and carbon storage, that depend on underlying ecosystem processes related to carbon (C), water, and nitrogen (N) cycling (Lindquist et al. 2012). Many experiments and observational studies have been conducted with the aim to better understand the potential effects of rising temperature, rising atmospheric $\mathrm{CO}_{2}$, and changing precipitation regimes on these forest ecosystem processes. For example, $\mathrm{CO}_{2}$-enrichment experiments in forests suggest net primary productivity will increase under elevated $\mathrm{CO}_{2}$, although this response can diminish over time because of water or nutrient limitation (Norby et al. 2010; Norby and Zak 2011; Kallarackal and Roby 2012). Reduced stomatal conductance to water vapor is also well-documented under elevated $\mathrm{CO}_{2}$, with little evidence of acclimation (Medlyn et al. 2001). Climate change experiments document a range of ecosystem responses, although for high-latitude systems projected warming often

Received 9 January 2013. Accepted 16 July 2013.

E.B. Peters. Institute on the Environment, University of Minnesota, Saint Paul, MN, USA.

K.R. Wythers. Forest Resources Department, University of Minnesota, Saint Paul, MN, USA.

S. Zhang. Supercomputing Institute, University of Minnesota, Minneapolis, MN, USA.

J.B. Bradford. US Geological Survey, Southwest Biological Science Center, Flagstaff, AZ, USA

P.B. Reich. Institute on the Environment, University of Minnesota, Saint Paul, MN, USA; Forest Resources Department, University of Minnesota, Saint Paul, MN, USA; Hawkesbury Institute for the Environment, University of Western Sydney, Penrith, Australia.

Corresponding author: Emily B. Peters (e-mail: ebpeters@umn.edu). 
increases process rates (Gunderson et al. 2000; Aerts et al. 2006; Hyvonen et al. 2007).

While these manipulative field studies provide useful insight into how forests respond to individual environmental change factors, logistical constraints often prevent the examination of complex and antagonistic interactions between multiple and simultaneously changing environmental factors (Frelich and Reich 2010; Fisichelli et al. 2012). For example, increases in productivity under elevated $\mathrm{CO}_{2}$ can be partially offset by reductions in productivity from warming-induced drought stress (Dieleman et al. 2012). Additionally, studies typically conducted at plot or stand scales and over relatively short time scales leave gaps in our understanding about the long-term effects of climate change at landscape and regional scales. Ecosystem models, therefore, can be useful tools for assessing the relative importance and impact of different environmental change factors on regional forest ecosystems (Medlyn et al. 2011).

In this study, we applied the ecosystem model PnET-CN to compare the long-term effects of two potential future climate and atmospheric $\mathrm{CO}_{2}$ scenarios on ecosystem function in forests across the Great Lakes region of North America. The Great Lakes region is an ideal landscape in which to examine the effects of climate change on forest ecosystem function because it contains a diversity of forest types and exists at the intersection of three major biomes (northern boreal forests, southern hardwood forests, and western tall-grass prairie). Thus, forests in this area may be particularly sensitive to environmental change (Scheller and Mladenoff 2008; Galatowitsch et al. 2009; Frelich and Reich 2010). Previous climate change projections in the region suggest that by 2069, the average annual temperature will increase by $3{ }^{\circ} \mathrm{C}$ and precipitation will increase by $6 \%$ (Galatowitsch et al. 2009).

Several previous studies have applied PnET-CN to evaluate past and future climate change effects on forest ecosystem processes (Ollinger et al. 2002, 2008; Pan et al. 2009), yet most of these simulations occurred at the stand scale and without the realistic respiration algorithms recently incorporated into PnET-CN (Wythers et al. 2013). No studies to date have applied PnET-CN to evaluate potential long-term climate change effects on future ecosystem function at the regional scale. In this study, our main objectives were to (1) compare the long-term (1960-2099) effects of two potential future climate and atmospheric $\mathrm{CO}_{2}$ scenarios (PCM B1 and GFDL A1FI) on productivity, evapotranspiration, runoff, and net $\mathrm{N}$ mineralization in forests across the Great Lakes region; and (2) assess the relative importance of spatially defined drivers, including forest type and edaphic and climatic conditions, on the variability in ecosystem responses across the region.

\section{Methods}

\section{Study region}

The northern Great Lakes region of the United States $\left(40.3^{\circ}-\right.$ $50.3^{\circ} \mathrm{N}$ latitude and $80.5^{\circ}-97.2^{\circ} \mathrm{W}$ longitude), also known as the Laurentian Mixed Forest Province, covers 26 million hectares (Bailey 1995). Forests in this region include six major forest types: aspen-birch (30\%), maple-beech-birch (26\%), spruce-fir (20\%), pine (10\%), oak-hickory ( $9 \%$ ), and elm-ash-cottonwood (5\%) (Wilson et al. 2012). Aspen-birch, elm-ash-cottonwood, and pine forests are distributed relatively evenly throughout the region, whereas spruce-fir forests are most abundant in northern Minnesota and upper Michigan, maple-beech-birch forests in northern Wisconsin and upper Michigan, and oak-hickory forests along the southern edge of the region (Fig. 1). The climate is characterized by short mild summers and long cold winters with a north-south gradient in mean annual temperature that ranges from $1{ }^{\circ} \mathrm{C}$ in northern Minnesota to $9{ }^{\circ} \mathrm{C}$ in central Michigan and an east-west gradient in annual precipitation that ranges from $530 \mathrm{~mm}$ in central Min-
Fig. 1. Distribution of six forest types across the northern Great Lakes region of the United States, also known as the Laurentian Mixed Forest Province. Figure 1 is available in color online.

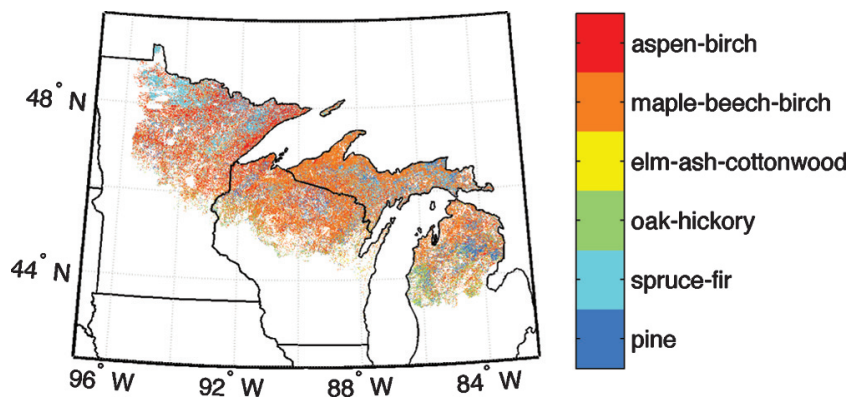

nesota to $940 \mathrm{~mm}$ in Michigan (Stoner et al. 2012). Soils are derived from glacial outwash and include sands, silt loams, and clays.

\section{PnET-CN model description}

PnET-CN is a widely used and, in some regions, well-tested ecosystem model that simulates $\mathrm{C}$, water, and $\mathrm{N}$ dynamics in forests over time (Aber et al. 1997; Ollinger et al. 2002; Peters et al. 2012). The PnET suite of models use generalized empirical relationships between foliar $\mathrm{N}$, photosynthetic capacity, vertical scaling of leaf mass per area, and leaf lifespan (Ellsworth and Reich 1993; Reich et al. 1998) to simulate photosynthesis and transpiration in a multilayered canopy (Aber et al. 1996). The canopy model is nested within a model that estimates respiration, $C$ allocation, and water balances (Aber et al. 1995), which is further nested within a model of biomass accumulation, decomposition, and $\mathrm{N}$ cycling (Aber et al. 1997). PnET-CN accounts for physiological and biogeochemical feedbacks by allowing $\mathrm{C}$, water, and $\mathrm{N}$ cycles to interact with each other, which enables the model to simulate both water and $\mathrm{N}$ limitations on productivity. A strength of the PnET-CN model is its ability to self-generate canopy $\mathrm{N}$ concentrations and leaf area index, as well as to simulate forest responses over time to many simultaneously changing environmental factors, including climate, $\mathrm{N}$ deposition, tropospheric ozone, atmospheric $\mathrm{CO}_{2}$, and land-use history (Aber et al. 1997, 2002; Ollinger et al. 2002). More recently, the model has been modified to incorporate respiration acclimation of plants to changes in temperature (Wythers et al. 2013). Model outputs have been previously corroborated in the Great Lakes region for current forest productivity, net $\mathrm{N}$ mineralization, leaf area index, and foliar $\mathrm{N}$ concentrations (Peters et al. 2012).

While PnET is not a spatially dynamic model, it can be applied to large geographic regions where each grid cell represents an independent simulation (Ollinger et al. 1998; McNeil et al. 2006; Pan et al. 2009). The number of calculations required to run PnET-CN across our study region using $1 \mathrm{~km} \times 1 \mathrm{~km}$ grid cells (159 072 total forest cells), however, created an impractical computational challenge for a single multicore computer. We developed a distributed parallel-computing framework for PnET-CN to reduce the computing time from 60 days (if the simulation ran sequentially) to $5 \mathrm{~h}$ by using 96 cores on a Linux cluster. This approach also included the functionality of fault tolerance (checkpointing), efficient $\mathrm{I} / \mathrm{O}$ management, and is expandable for integrating other ecological models and exploring horizontal flows between grid cells, although cell interactions were not incorporated in the runs reported here.

\section{Model inputs}

PnET-CN requires input information on climate, atmospheric conditions, soils, and vegetation. We used gridded $(\sim 13 \mathrm{~km})$ monthly temperature and precipitation data from 1960 to 2099 from two statistically downscaled climate projections (PCM B1 and GFDL A1FI) (Stoner et al. 2012). These two climate projections 
Fig. 2. Change in (A, B) minimum mean annual temperature (Tmin) in ${ }^{\circ} \mathrm{C},(\mathrm{C}, \mathrm{D})$ maximum mean annual temperature $(\mathrm{Tmax})$ in ${ }^{\circ} \mathrm{C}$, and $(\mathrm{E}, \mathrm{F})$ annual precipitation in cm under the PCM B1 and GFDL A1FI climate scenarios, respectively, from 1971-2000 to 2070-2099 across the northern Great Lakes region of the United States. Figure 2 is available in color online.

A. PCM B1: Tmin change $\left({ }^{\circ} \mathrm{C}\right)$

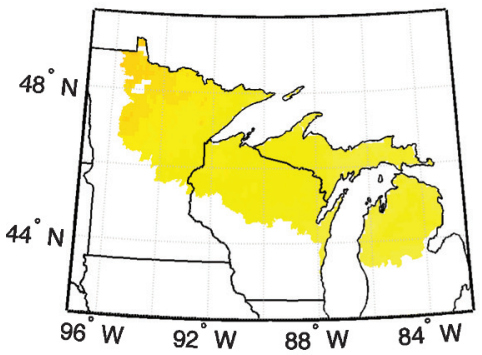

C. PCM B1: Tmax change $\left({ }^{\circ} \mathrm{C}\right)$

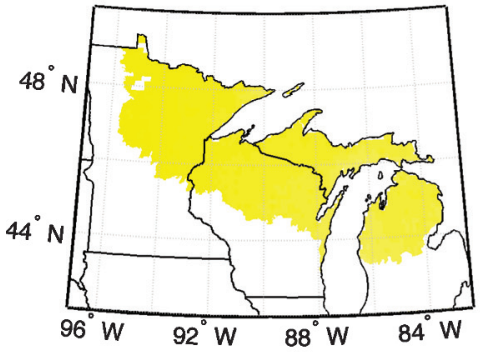

E. PCM B1: precipitation change (cm)

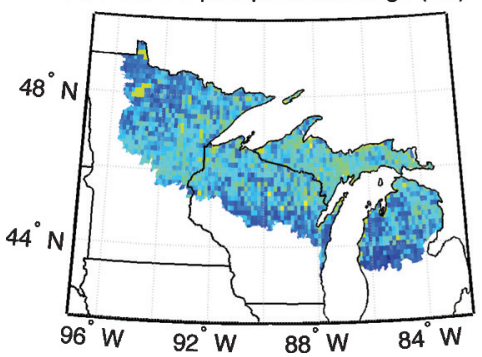

B. GFDL A1FI: Tmin change $\left({ }^{\circ} \mathrm{C}\right)$

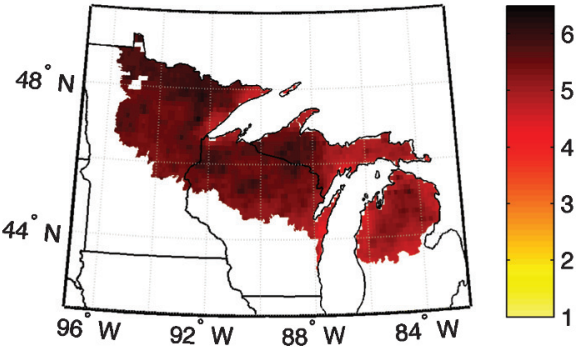

D. GFDL A1FI: Tmax change $\left({ }^{\circ} \mathrm{C}\right)$

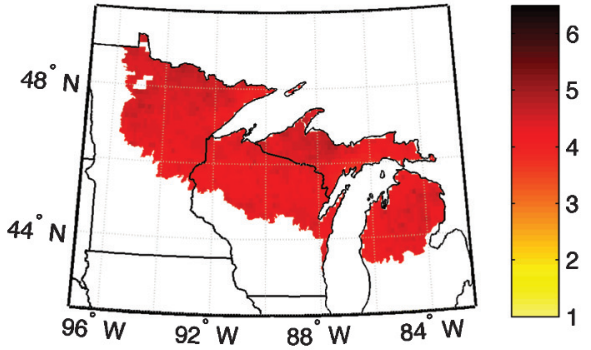

F. GFDL A1FI: precipitation change $(\mathrm{cm})$

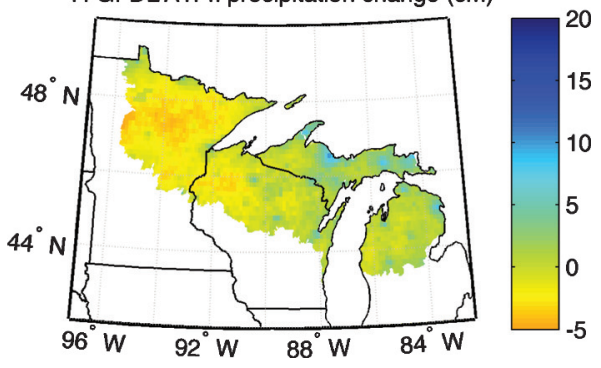

encompass a wide range in potential future $\mathrm{CO}_{2}$ emissions (B1, low emissions; A1FI, high emissions) and sensitivities among general circulation models (PCM, low sensitivity; GFDL, high sensitivity). $\mathrm{CO}_{2}$ concentrations rise over time under both the PCM B1 and GFDL A1FI scenarios, reaching 548 and 970 ppm, respectively, by 2099. From 1971-2000 to 2070-2099, the PCM B1 scenario predicts a regional average increase in mean annual temperature of $1.5^{\circ} \mathrm{C}$ and an increase in annual precipitation of $84 \mathrm{~mm}$, whereas the GFDL A1FI scenario predicts a $4.8{ }^{\circ} \mathrm{C}$ increase in mean annual temperature and $1 \mathrm{~mm}$ decline in annual precipitation (Fig. 2).

To separate the effects of climate and $\mathrm{CO}_{2}$ as drivers of forest ecosystem processes, we ran PnET-CN including and excluding the $\mathrm{CO}_{2}$ routine. In response to rising $\mathrm{CO}_{2}$, PnET-CN increases leaf photosynthetic rates using a saturating Michaelis-Menton equation and reduces stomatal conductance as a function of the $\mathrm{CO}_{2}$ concentration gradient across the leaf surface (Ollinger et al. 2002). When the $\mathrm{CO}_{2}$ routine was included, atmospheric $\mathrm{CO}_{2}$ concentrations were allowed to rise for each climate scenario. We excluded the $\mathrm{CO}_{2}$ routine and the effects of $\mathrm{CO}_{2}$ on photosynthesis and stomatal conductance from the model by holding $\mathrm{CO}_{2}$ concentrations equal to $350 \mathrm{ppm}$ for both climate scenarios.

We used solar radiation data measured at 169 sites across the study region between 1981 and 2011 (compiled by the Northern Institute of Applied Climate Science). Each site varied in the duration and time period of data collection. Because of poor spatial and temporal coverage of solar radiation measurements and the large uncertainty in future changes in solar radiation (Liepert
2002; Taylor 2012), we created spatial interpolations of mean monthly photosynthetically active radiation (PAR) that were applied across all years of our model simulations (e.g., Fig. 3A).

We used current modeled wet and dry nitrate $\left(\mathrm{NO}_{3}\right)$ and ammonium $\left(\mathrm{NH}_{4}\right)$ deposition data (Fig. 3B; http://www.epa.gov/amad/ Tools/wdt.html, 13 December 2012) and tropospheric ozone anomalies (Fig. 3C; B. Wells and D. Mintz, Environmental Protection Agency, personal communication (2011)). We assumed N deposition and ozone concentrations in 1930 were $20 \%$ and $10 \%$, respectively, of their contemporary levels and increased linearly to the present (Ollinger et al. 2008; Pan et al. 2009). Under future climate scenarios, feedback mechanisms will likely influence $\mathrm{N}$ deposition and ozone concentrations. Owing to the great uncertainty in future projections, especially for our study region (Galloway et al. 2004; Vingarzan 2004; Racherla and Adams 2006; Sitch et al. 2007), these feedbacks were not included in our simulations and we held current $\mathrm{N}$ deposition and ozone concentration values constant into the future. In PnET-CN, N deposition affects soil $\mathrm{C}$ and $\mathrm{N}$ pools, which affect rates of $\mathrm{N}$ supply to vegetation and $\mathrm{N}$ losses to drainage. Tropospheric ozone works to limit photosynthesis in the model, which in turn affects $\mathrm{C}$ allocation.

We used a gridded $(4 \mathrm{~km})$ soil water-holding capacity map of our study region (Fig. 3D) based on the National Conservation Resource Service's Soil Survey Geographic Database (M. Peters, personal communication (2011)). Water-holding capacity values were calculated based on soil texture and soil depth to $1 \mathrm{~m}$ from SSURGO (where available) and STATSGO data sets. 
Fig. 3. Gridded input data used to run the PnET-CN model across the northern Great Lakes region of the United States. (A) Spatial interpolation of mean instantaneous photosynthetically active radiation in $\mu \mathrm{mol} \cdot \mathrm{m}^{-2} \cdot \mathrm{s}^{-1}$ for the month of June. (B) Mean current (2002-2006) total dry and wet nitrogen (N) deposition including $\mathrm{NO}_{3}$ and $\mathrm{NH}_{4}$ in $\mathrm{kg} \mathrm{N} \cdot \mathrm{ha}^{-1} \cdot$ year ${ }^{-1}$. (C) Spatially interpolated mean current (2005-2009) AOT40 cumulative hourly ozone anomolies greater than the threshold of $40 \mathrm{ppb}$ from April to September in ppm-h. (D) Soil water-holding capacity in $\mathrm{cm}$. Figure 3 is available in color online.
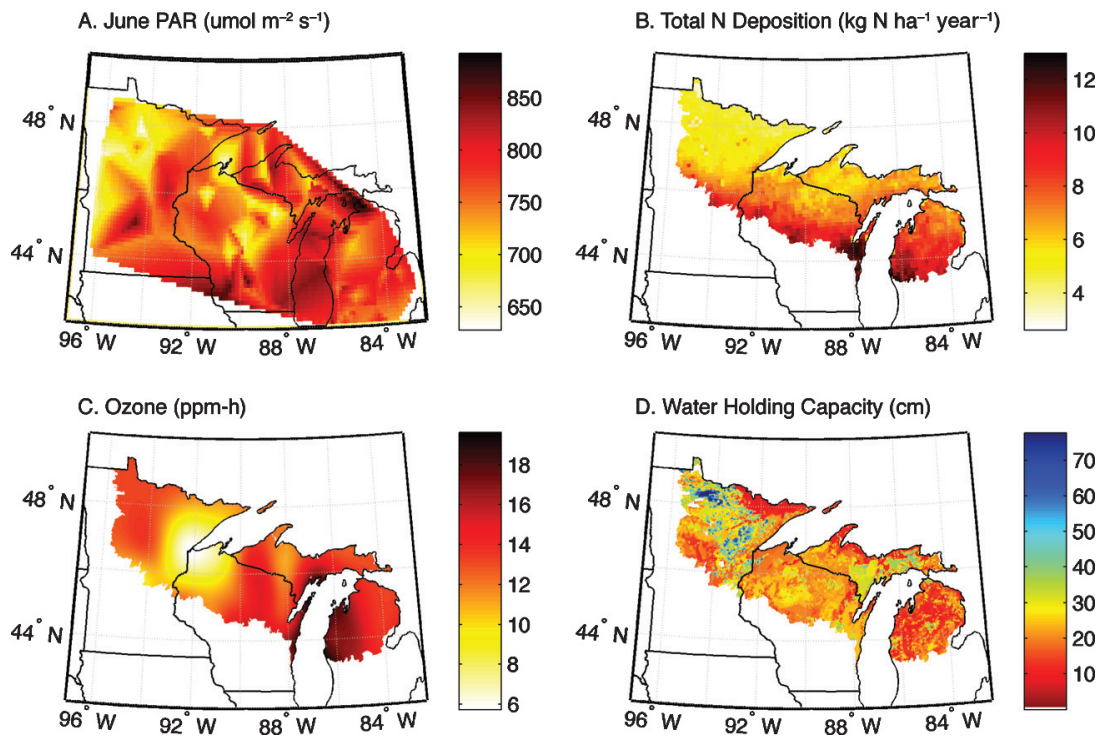

Current land cover composition across the study region was defined using a gridded $(1 \mathrm{~km})$ forest-type map based on USFS Forest Inventory and Analysis data and MODIS satellite imagery (Fig. 1) (Wilson et al. 2012). We parameterized these forest types following Peters et al. (2012) with a few slight modifications (Table 1). To reflect delayed wood production relative to foliage production in forest types dominated by diffuse-porous species (aspen-birch and maple-beech-birch), the growing degree-days required for wood production to start and end were changed to 764 and 1600 , respectively, from 332 and 764, respectively, for ring-porous species. Leaf mass per area at the top of the canopy was set equal to $91 \mathrm{~g} \cdot \mathrm{m}^{-2}$ for aspen-birch, $70 \mathrm{~g} \cdot \mathrm{m}^{-2}$ for maple-beech-birch, $73 \mathrm{~g} \cdot \mathrm{m}^{-2}$ for elm-ash-cottonwood, and $87 \mathrm{~g} \cdot \mathrm{m}^{-2}$ for oak-hickory (Ravenscroft et al. 2010). PnET-CN holds forest composition static over time, as it is not a spatially explicit model and does not represent ecological processes such as succession or migration. Neither we, nor the model developers, assume this to be likely; instead the model is used to explore how productivity would change holding composition constant, as allowing both composition and climate to vary makes it more challenging to understand the mechanisms of shifts in productivity.

Our analyses focused on changes in aboveground net primary productivity (ANPP) because modeled ANPP has been previously validated in the Great Lakes region (Peters et al. 2012), ANPP represents a familiar measure of productivity to forest managers, and our collective understanding of belowground production is still so poor that modeling it is extremely challenging. The long-term effects of future climate scenarios were evaluated by comparing two discrete time periods, current (1971- 2000) and future (20702099), following meteorological convention that defines climate averages over 30 years. To assess the importance of climatic and spatial drivers on ANPP, we calculated Pearson correlations between ANPP and temperature, precipitation, and water-holding capacity by forest type across the study region. All analyses were performed using Matlab (version 2012b). We did not test for statistically significant differences between model simulations, as stochasticity was not incorporated into individual PnET-CN runs.

\section{Results}

\section{Productivity}

We found that predicted changes in ANPP from 1971-2000 to 2070-2099 varied widely, depending on the climate scenario and direct $\mathrm{CO}_{2}$ effects (Fig. 4). With the $\mathrm{CO}_{2}$ routine implemented in PnET-CN, average regional ANPP increased under both climate scenarios, but showed a smaller average increase of $372 \mathrm{~g} \cdot \mathrm{m}^{-2}$.year ${ }^{-1}$ (67\%) under the PCM B1 scenario (Fig. 4A) compared with $750 \mathrm{~g} \cdot \mathrm{m}^{-2}$.year-1 (142\%) under the GFDL A1FI scenario (Fig. 4B). When the $\mathrm{CO}_{2}$ routine was not implemented in the model, average regional ANPP did not change under the PCM B1 scenario (Fig. 4C) and declined by $-103 \mathrm{~g} \cdot \mathrm{m}^{-2}$.year ${ }^{-1}(-18 \%)$ under the GFDL A1FI scenario (Fig. 4D). These results suggest ANPP is sensitive to both changes in climate and $\mathrm{CO}_{2}$ and that responses to future warming are likely to be larger because of rising $\mathrm{CO}_{2}$.

Changes in predicted ANPP varied markedly across the region. With the $\mathrm{CO}_{2}$ routine implemented, the increases in ANPP under the PCM B1 scenario ranged from 64 to $821 \mathrm{~g} \cdot \mathrm{m}^{-2}$.year-1 or $+9 \%$ to $+134 \%$ (Fig. 4A), and under the GFDL A1FI scenario the increases ranged from 7 to $1493 \mathrm{~g} \cdot \mathrm{m}^{-2}$.year ${ }^{-1}$ or $+6 \%$ to $+254 \%$ (Fig. 4B). Under both climate scenarios, the largest increases in ANPP occurred in eastern Minnesota, northern Wisconsin, and upper Michigan (the cooler, moister part of the region), whereas the smallest changes in ANPP occurred in the northwestern part of the region, in northern Minnesota.

Changes in ANPP also varied by forest type. Under both climate scenarios with the $\mathrm{CO}_{2}$ routine implemented, the four deciduous forest types (aspen-birch, oak-hickory, maple-beech-birch, and elm-ash-cottonwood) had the highest average regional ANPP from 1960 to 2099 (Fig. 5), as well as the largest increases in average regional ANPP, followed by pine and spruce-fir forests (Table 2). For all forest types, average regional ANPP peaked around the year 2080 under the PCM B1 scenario (Fig. 5A), yet continued to rise until 2099 under the GFDL A1FI scenario (Fig. 5B).

Within a given forest type, the relative importance of different spatial drivers of ANPP varied over time. For all deciduous forest types, spatial differences in current ANPP were most strongly and positively correlated with summer temperature, summer 
Table 1. Vegetation parameters in PnET-CN representing aspen-birch, elm-ash-cottonwood, maple-beech-birch, oak-hickory, pine, and spruce-fir forest types.

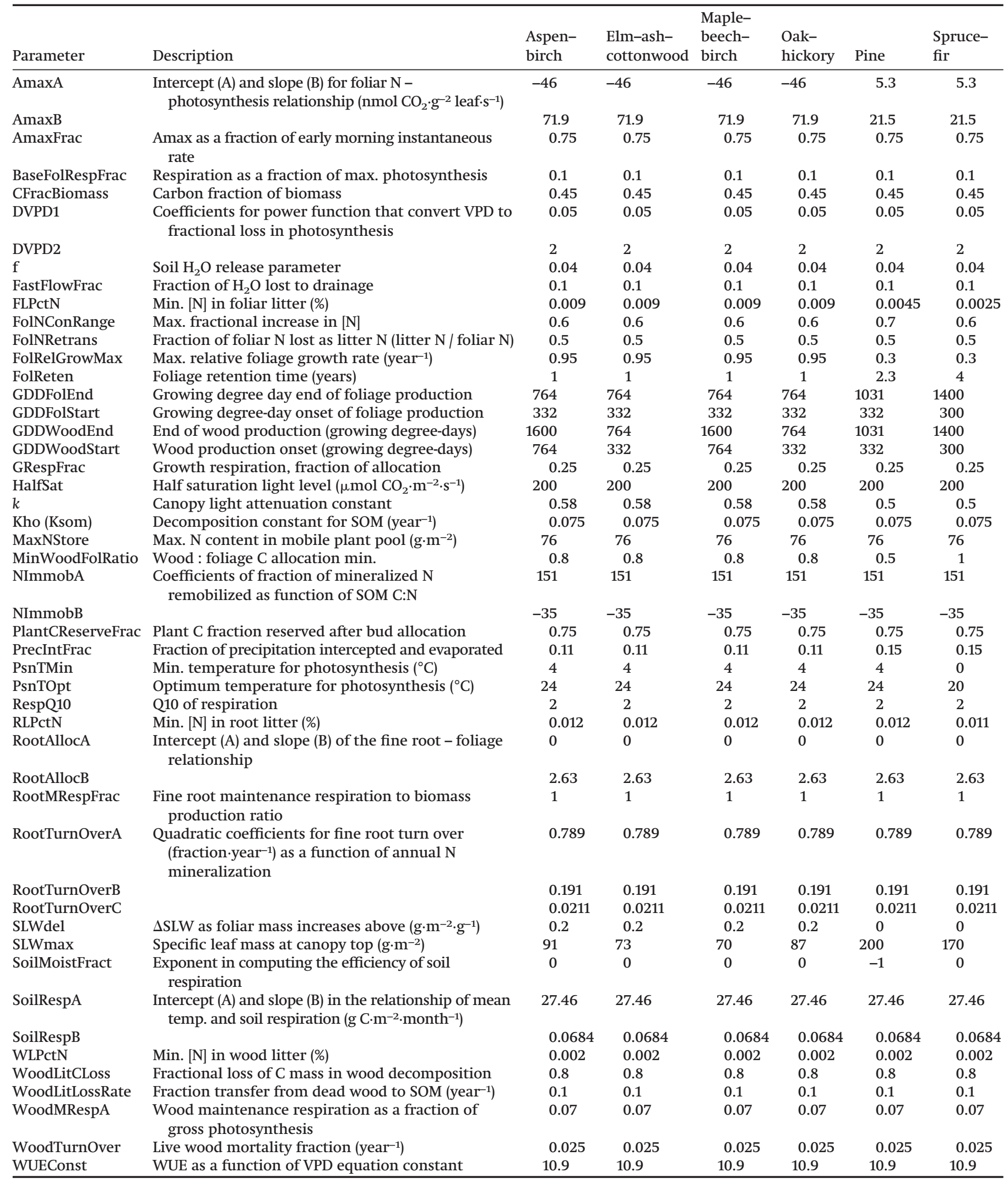

Note: VPD, vapor pressure deficit; SOM, soil organic matter; WUE, water use efficiency. 
Fig. 4. Change in aboveground net primary productivity (ANPP) in $\mathrm{g}$ biomass $\cdot \mathrm{m}^{-2} \cdot \mathrm{year}{ }^{-1}$ from $1971-2000$ to $2070-2099$ across the northern Great Lakes region of the United States under two climate scenarios (PCM B1 and GFDL A1FI) with and without the $\mathrm{CO}_{2}$ routine implemented in PnET-CN. Figure 4 is available in color online.
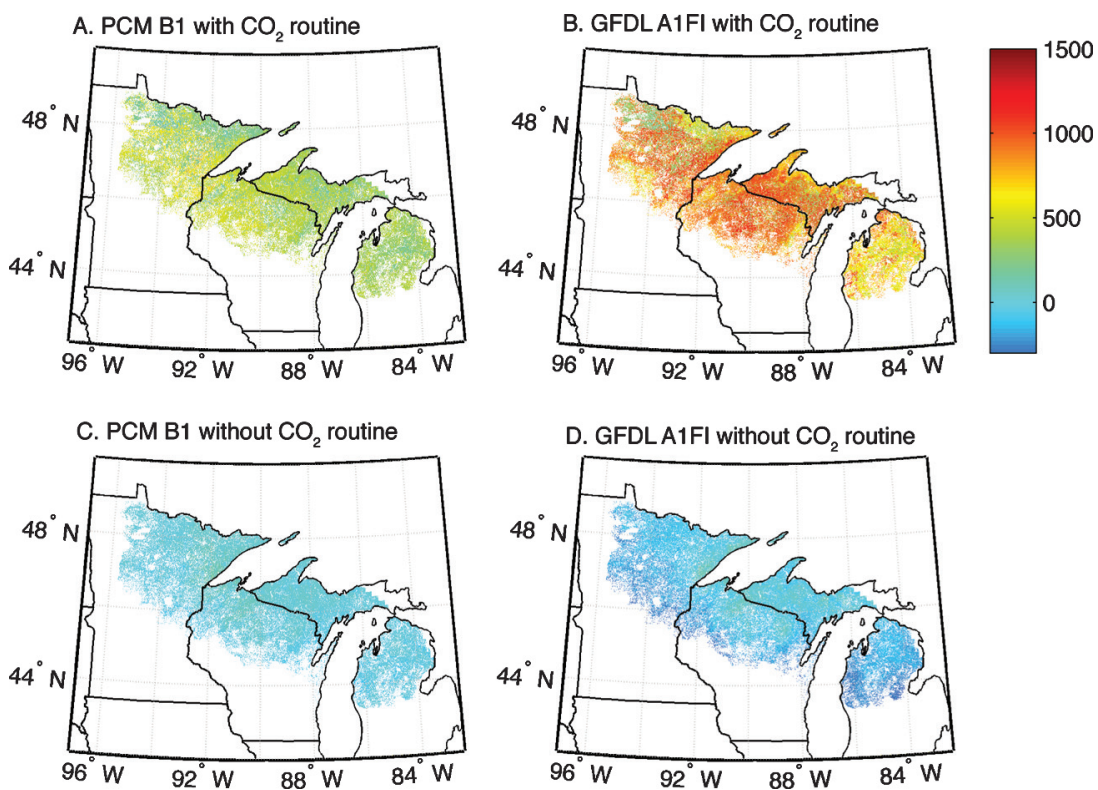

Fig. 5. Average aboveground net primary productivity (ANPP) in $\mathrm{g}$ biomass $\cdot \mathrm{m}^{-2} \cdot \mathrm{year}^{-1}$ from 1960 to 2099 across the northern Great Lakes region of the United States for six forest types under two climate scenarios (PCM B1 and GFDL A1FI) with and without the $\mathrm{CO}_{2}$ routine implemented in PnET-CN. Box-and-whisker plots show median (-), 25th and 75th percentiles (box), and extreme ANPP values (whiskers) by forest type for the year 2099. Figure 5 is available in color online.
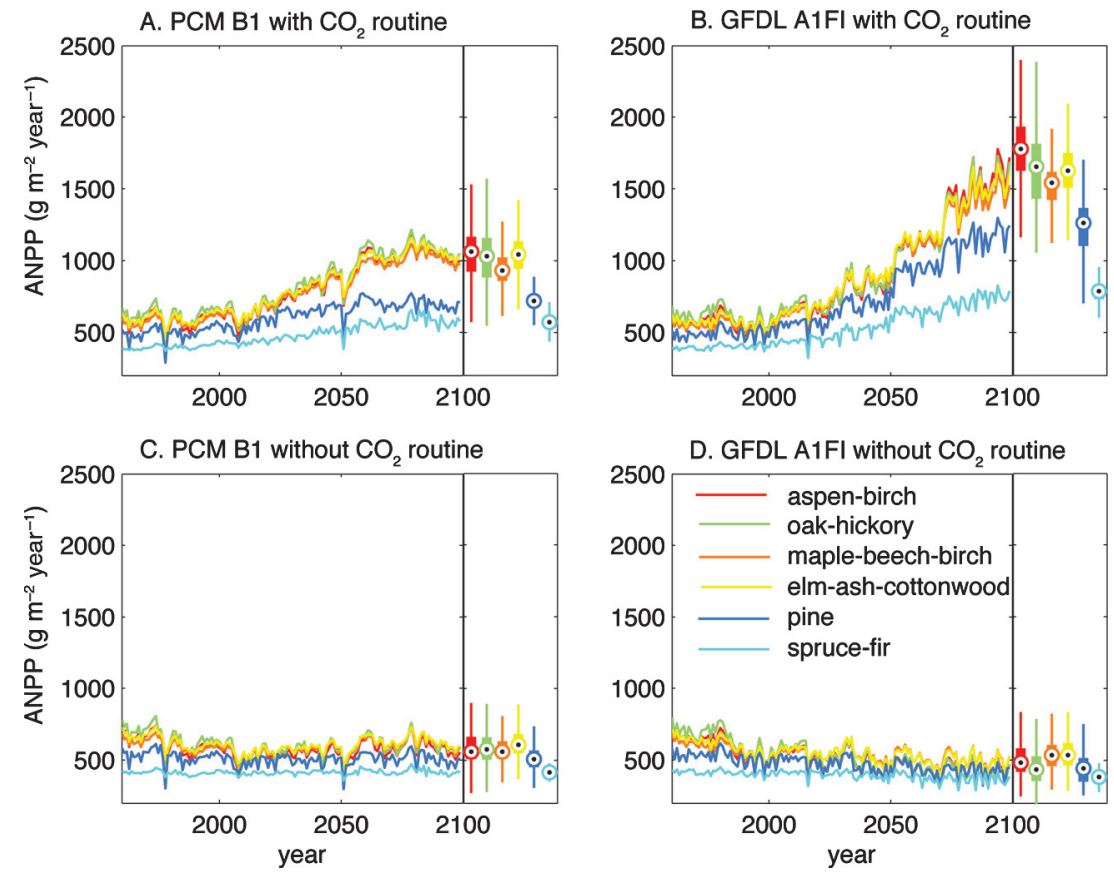

precipitation, and soil water-holding capacity (Supplementary data Table 4$),{ }^{1}$ whereas spatial differences in future ANPP were most strongly and positively correlated with summer precipitation and water-holding capacity (Supplementary data Table 5). ${ }^{1}$ This pattern was the same for pine forests, except spatial differences in future ANPP under the PCM B1 scenario were most strongly and positively correlated with summer temperature and

water-holding capacity. For spruce-fir forests, spatial differences in current ANPP were instead most strongly and positively correlated with annual temperature and annual precipitation, whereas spatial differences in future ANPP were most strongly and positively correlated with annual temperature and water holding capacity under the PCM B1 scenario and most strongly and negatively correlated with summer temperature under the GFDL A1FI 
Table 2. Predicted changes from 1971-2000 to 2070-2099 in mean ( \pm 1 standard deviation) regional aboveground net primary productivity (ANPP), evapotranspiration, runoff, and net $\mathrm{N}$ mineralization by forest type under two climate change scenarios with and without implementing the $\mathrm{CO}_{2}$ routine of PnET-CN.

\begin{tabular}{|c|c|c|c|c|c|c|}
\hline Ecosystem function & $\begin{array}{l}\text { Aspen- } \\
\text { birch }\end{array}$ & $\begin{array}{l}\text { Elm-ash- } \\
\text { cottonwood }\end{array}$ & $\begin{array}{l}\text { Maple-beech- } \\
\text { birch }\end{array}$ & $\begin{array}{l}\text { Oak- } \\
\text { hickory }\end{array}$ & Pine & $\begin{array}{l}\text { Spruce- } \\
\text { fir }\end{array}$ \\
\hline \multicolumn{7}{|l|}{ ANPP (g biomass $\cdot \mathrm{m}^{-2} \cdot$ year $^{-1}$ ) } \\
\hline PCM B1 with $\mathrm{CO}_{2}$ routine & $465(31)$ & $459(20)$ & $439(15)$ & $454(25)$ & $190(17)$ & $174(7)$ \\
\hline GFDL A1FI with $\mathrm{CO}_{2}$ routine & $934(60)$ & $882(57)$ & $855(41)$ & $853(55)$ & $643(41)$ & $322(12)$ \\
\hline PCM B1 without $\mathrm{CO}_{2}$ routine & $-13(11)$ & $8(17)$ & $21(12)$ & $-31(13)$ & $-14(8)$ & $7(3)$ \\
\hline GFDL A1FI without $\mathrm{CO}_{2}$ routine & $-148(25)$ & $-95(36)$ & $-62(23)$ & $-200(29)$ & $-94(22)$ & $-44(9)$ \\
\hline \multicolumn{7}{|c|}{ Evapotranspiration $\left(\mathbf{c m} \cdot\right.$ year $\left.^{-1}\right)$} \\
\hline PCM B1 with $\mathrm{CO}_{2}$ routine & $4.1(0.5)$ & $3.1(0.6)$ & $2.8(0.4)$ & $3.9(0.6)$ & $2.3(0.5)$ & $1.2(0.2)$ \\
\hline GFDL A1FI with $\mathrm{CO}_{2}$ routine & $-0.9(1.0)$ & $0.2(1.2)$ & $0.8(0.8)$ & $-2.9(1.1)$ & $-1.6(1.5)$ & $-3.3(0.7)$ \\
\hline PCM B1 without $\mathrm{CO}_{2}$ routine & $7.5(0.7)$ & $8.9(1.1)$ & $8.8(0.8)$ & $7.0(0.8)$ & $6.9(0.7)$ & $5.6(0.2)$ \\
\hline \multirow{2}{*}{\multicolumn{7}{|c|}{ Runoff $\left(\mathbf{c m} \cdot\right.$ year $\left.^{-1}\right)$}} \\
\hline & & & & & & \\
\hline PCM B1 with $\mathrm{CO}_{2}$ routine & $4.2(0.4)$ & $5.6(0.9)$ & $5.2(0.6)$ & $5.0(0.7)$ & $6.1(0.7)$ & $7.0(0.7)$ \\
\hline GFDL A1FI with $\mathrm{CO}_{2}$ routine & $0.5(1.0)$ & $-0.9(1.2)$ & $-1.3(0.8)$ & $2.3(1.1)$ & $1.0(1.4)$ & $3.1(0.6)$ \\
\hline PCM B1 without $\mathrm{CO}_{2}$ routine & $0.9(0.9)$ & $-0.1(1.2)$ & $-0.7(0.8)$ & $1.9(0.9)$ & $1.5(0.8)$ & $2.6(0.7)$ \\
\hline GFDL A1FI without $\mathrm{CO}_{2}$ routine & $-2.3(1.5)$ & $-5.5(2.2)$ & $-6.3(1.7)$ & $-0.4(1.4)$ & $-0.9(1.9)$ & $-4.3(0.6)$ \\
\hline \multicolumn{7}{|c|}{ Net $\mathrm{N}$ mineralization $\left(\mathrm{g} \mathrm{N} \cdot \mathrm{m}^{-2} \cdot\right.$ year $^{-1}$ ) } \\
\hline PCM B1 with $\mathrm{CO}_{2}$ routine & $0.5(0.3)$ & $0.7(0.2)$ & $0.7(0.2)$ & $0.4(0.2)$ & $1.0(0.3)$ & $1.1(<0.1)$ \\
\hline GFDL A1FI with $\mathrm{CO}_{2}$ routine & $0.6(0.5)$ & $1.4(0.4)$ & $1.4(0.3)$ & $0.0(0.5)$ & $0.8(0.8)$ & $1.3(0.2)$ \\
\hline PCM B1 without $\mathrm{CO}_{2}$ routine & $-0.8(0.2)$ & $-0.2(0.3)$ & $-0.1(0.2)$ & $-1.0(0.2)$ & $-0.9(0.3)$ & $0.3(<0.1)$ \\
\hline GFDL A1FI without $\mathrm{CO}_{2}$ routine & $-1.6(0.4)$ & $-0.6(0.4)$ & $-0.5(0.3)$ & $-2.3(0.4)$ & $-3.1(0.6)$ & $0.4(0.1)$ \\
\hline
\end{tabular}

Table 3. Correlation coefficients of the relationship between change in aboveground net primary productivity (ANPP) from 1971-2000 to 2070-2099 and climatic and edaphic spatial drivers by forest type under two climate change scenarios with and without implementing the $\mathrm{CO}_{2}$ routine of PnET-CN.

\begin{tabular}{|c|c|c|c|c|c|c|}
\hline Spatial driver & $\begin{array}{l}\text { Aspen- } \\
\text { birch }\end{array}$ & $\begin{array}{l}\text { Elm-ash- } \\
\text { cottonwood }\end{array}$ & $\begin{array}{l}\text { Maple-beech- } \\
\text { birch }\end{array}$ & $\begin{array}{l}\text { Oak- } \\
\text { hickory }\end{array}$ & Pine & $\begin{array}{l}\text { Spruce- } \\
\text { fir }\end{array}$ \\
\hline \multicolumn{7}{|l|}{ PCM B1 with $\mathrm{CO}_{2}$ routine } \\
\hline 2070-2099 annual Tmin & -0.26 & -0.53 & -0.40 & -0.39 & 0.13 & 0.24 \\
\hline 2070-2099 annual Tmax & -0.14 & -0.51 & -0.21 & -0.50 & 0.15 & 0.18 \\
\hline 2070-2099 annual precipitation & -0.19 & -0.25 & 0.00 & -0.13 & 0.01 & -0.02 \\
\hline 2070-2099 summer Tmin & 0.09 & -0.17 & 0.03 & 0.09 & -0.07 & 0.25 \\
\hline 2070-2099 summer Tmax & 0.15 & -0.08 & 0.19 & -0.05 & -0.04 & 0.20 \\
\hline 2070-2099 summer precipitation & 0.49 & 0.55 & 0.66 & 0.59 & -0.22 & -0.09 \\
\hline Water-holding capacity & 0.64 & 0.57 & 0.58 & 0.63 & -0.14 & 0.27 \\
\hline \multicolumn{7}{|l|}{ GFDL A1FI with $\mathrm{CO}_{2}$ routine } \\
\hline 2070-2099 annual Tmin & -0.18 & -0.48 & -0.42 & -0.36 & -0.25 & 0.14 \\
\hline 2070-2099 annual Tmax & -0.25 & -0.57 & -0.40 & -0.53 & -0.40 & -0.34 \\
\hline 2070-2099 annual precipitation & 0.05 & -0.09 & 0.07 & -0.09 & 0.11 & 0.30 \\
\hline 2070-2099 summer Tmin & -0.11 & -0.30 & -0.22 & -0.09 & -0.20 & -0.58 \\
\hline 2070-2099 summer Tmax & -0.23 & -0.48 & -0.33 & -0.45 & -0.41 & -0.67 \\
\hline 2070-2099 summer precipitation & 0.33 & 0.54 & 0.49 & 0.51 & 0.39 & -0.12 \\
\hline Water-holding capacity & 0.56 & 0.56 & 0.64 & 0.63 & 0.56 & -0.31 \\
\hline \multicolumn{7}{|l|}{ PCM B1 without $\mathrm{CO}_{2}$ routine } \\
\hline 2070-2099 annual Tmin & -0.53 & -0.70 & -0.62 & -0.22 & -0.68 & -0.48 \\
\hline 2070-2099 annual Tmax & -0.55 & -0.71 & -0.61 & -0.15 & -0.69 & -0.64 \\
\hline 2070-2099 annual precipitation & -0.15 & -0.17 & 0.03 & 0.05 & -0.16 & 0.04 \\
\hline 2070-2099 summer Tmin & -0.59 & -0.68 & -0.49 & -0.40 & -0.66 & -0.76 \\
\hline 2070-2099 summer Tmax & -0.48 & -0.58 & -0.36 & -0.27 & -0.60 & -0.62 \\
\hline 2070-2099 summer precipitation & 0.31 & 0.44 & 0.49 & 0.18 & 0.33 & -0.01 \\
\hline Water-holding capacity & -0.15 & 0.19 & 0.24 & -0.27 & 0.12 & -0.37 \\
\hline \multicolumn{7}{|c|}{ GFDL A1FI without $\mathrm{CO}_{2}$ routine } \\
\hline 2070-2099 annual Tmin & -0.45 & -0.67 & -0.62 & -0.57 & -0.62 & -0.10 \\
\hline 2070-2099 annual Tmax & -0.67 & -0.78 & -0.74 & -0.57 & -0.76 & -0.56 \\
\hline 2070-2099 annual precipitation & 0.09 & -0.05 & 0.08 & -0.02 & 0.02 & 0.26 \\
\hline 2070-2099 summer Tmin & -0.78 & -0.74 & -0.63 & -0.76 & -0.68 & -0.79 \\
\hline 2070-2099 summer Tmax & -0.79 & -0.80 & -0.69 & -0.69 & -0.77 & -0.84 \\
\hline 2070-2099 summer precipitation & 0.47 & 0.65 & 0.59 & 0.37 & 0.64 & 0.12 \\
\hline Water-holding capacity & -0.08 & 0.20 & 0.32 & 0.04 & 0.34 & -0.39 \\
\hline
\end{tabular}

Note: Climatic drivers have a spatial resolution of $\sim 13 \mathrm{~km}$ (Stoner et al. 2012), whereas water-holding capacity has a spatial resolution of $4 \mathrm{~km}$ (M. Peters, personal communication (2011)). 
Fig. 6. Change in evapotranspiration in $\mathrm{cm} \cdot \mathrm{year}^{-1}$ from 1971-2000 to 2070-2099 across the northern Great Lakes region of the United States under two climate scenarios (PCM B1 and GFDL A1FI) with and without the $\mathrm{CO}_{2}$ routine implemented in PnET-CN. Figure 6 is available in color online.


scenario (Supplementary data Table 5$).{ }^{1}$ For nearly all forest types, spatial differences in predicted changes in ANPP under both climate scenarios with the $\mathrm{CO}_{2}$ routine implemented were most strongly and positively correlated with future summer precipitation and soil water-holding capacity (Table 3). When the $\mathrm{CO}_{2}$ routine was not implemented, spatial differences in predicted changes in ANPP were most strongly and negatively correlated with future temperature, suggesting the important role that $\mathrm{CO}_{2}$ fertilization plays in allowing forests to overcome warminginduced drought stress through increased water-use efficiency.

Growing season length, as defined by the first and last month of the year with a positive net $C$ balance, increased by 1-2 months under both climate projections by 2070-2099 (data not shown). However, the increase in growing season length coincided with a decline in mid-summer net $C$ uptake. Across the growing season and under both climate scenarios, net $C$ uptake was higher with the $\mathrm{CO}_{2}$ routine implemented than without.

\section{Evapotranspiration and runoff}

Predicted changes in evapotranspiration and runoff from 19712000 to 2070-2099 varied widely, depending on the climate scenario and direct $\mathrm{CO}_{2}$ effects (Figs. 6 and 7). Under the PCM B1 scenario with the $\mathrm{CO}_{2}$ routine, average regional evapotranspiration increased by $3 \mathrm{~cm} \cdot$ year $^{-1}(+6 \%)$ and average regional runoff increased by $5 \mathrm{~cm} \cdot$ year $^{-1}(+22 \%)$. Under the GFDL A1FI scenario with the $\mathrm{CO}_{2}$ routine, average regional evapotranspiration declined by $1 \mathrm{~cm} \cdot$ year $^{-1}(-3 \%)$, whereas average regional runoff increased by $1 \mathrm{~cm} \cdot$ year $^{-1}(+2 \%)$. When the $\mathrm{CO}_{2}$ routine was not implemented, average regional evapotranspiration increased by $7 \mathrm{~cm} \cdot$ year $^{-1}(+16 \%)$ under the PCM B1 scenario and by $3 \mathrm{~cm} \cdot$ year $^{-1}$ $(+7 \%)$ under the GFDL A1FI scenario, whereas average regional runoff increased by $1 \mathrm{~cm} \cdot$ year $^{-1}(4 \%)$ under the PCM B1 scenario and decreased by $3 \mathrm{~cm} \cdot$ year $^{-1}(-11 \%)$ under the GFDL A1FI scenario. These results suggest that climate (particularly precipitation inputs) and $\mathrm{CO}_{2}$ fertilization (through effects on stomatal conductance) are both important drivers of future annual evapotranspiration and runoff in the Great Lakes region.

Changes in evapotranspiration and runoff varied across the region. Under the PCM B1 scenario with the $\mathrm{CO}_{2}$ routine, changes in evapotranspiration ranged from -12 to $+13 \mathrm{~cm} \cdot$ year $^{-1}$ with the

largest increases in north-central Minnesota and lower Michigan (Fig. 6A), whereas changes in runoff ranged from -3 to $+20 \mathrm{~cm} \cdot$ year $^{-1}$ with the largest increases in northern Minnesota, central Wisconsin, and lower Michigan (Fig. 7A). Under the GFDL A1FI scenario with the $\mathrm{CO}_{2}$ routine, changes in evapotranspiration likewise ranged from -12 to $+12 \mathrm{~cm} \cdot$ year $^{-1}$ with the largest increases in lower Michigan (Fig. 6B), whereas changes in runoff ranged from -14 to $+12 \mathrm{~cm} \cdot$ year $^{-1}$ with the largest increases in lower Michigan (Fig. 7B).

Changes in water balance also varied by forest type (Table 2). Under the PCM B1 scenario with the $\mathrm{CO}_{2}$ routine, the four deciduous forest types showed the largest average regional increases in evapotranspiration, followed by pine and spruce-fir forests. Increases in runoff, however, were largest in spruce-fir forests, followed by pine and the four deciduous forest types. Under the GFDL A1FI scenario with the $\mathrm{CO}_{2}$ routine, maple-beech-birch and elm-ash-cottonwood forests showed moderate increases in average regional evapotranspiration, whereas spruce-fir showed the largest declines, followed by oak-hickory, pine, and aspen-birch forests.

\section{Net $\mathbf{N}$ mineralization}

Predicted changes in net $\mathrm{N}$ mineralization from 1971-2000 to 2070-2099 were moderate, regardless of the climate scenario or whether the $\mathrm{CO}_{2}$ routine was implemented (Fig. 8). Average regional net $\mathrm{N}$ mineralization increased by $0.7(10 \%)$ and $0.9(12 \%) \mathrm{g} \mathrm{N} \cdot \mathrm{m}^{-2}$. year-1 under the PCM B1 and GFDL A1FI scenarios with the $\mathrm{CO}_{2}$ routine, respectively. When the $\mathrm{CO}_{2}$ routine was not implemented, average regional net $\mathrm{N}$ mineralization declined by $0.4 \mathrm{~g} \mathrm{~N} \cdot \mathrm{m}^{-2} \cdot \mathrm{year}^{-1}$ $(-3 \%)$ under the PCM B1 scenario and by $1.1 \mathrm{~g} \mathrm{~N} \cdot \mathrm{m}^{-2} \cdot$ year $^{-1}(-10 \%)$ under the GFDL A1FI scenario. These results suggest net $\mathrm{N}$ mineralization is sensitive to both climate and $\mathrm{CO}_{2}$ and that increases in net $\mathrm{N}$ mineralization are only substantive when both temperature and $\mathrm{CO}_{2}$ increase.

Changes in net $\mathrm{N}$ mineralization varied across the region. When the $\mathrm{CO}_{2}$ routine was implemented, changes in net $\mathrm{N}$ mineralization under the PCM B1 scenario ranged from -2.5 to $+5.4 \mathrm{~g} \mathrm{~N} \cdot \mathrm{m}^{-2}$.year ${ }^{-1}$ or $-16 \%$ to $+52 \%$ (Fig. $8 \mathrm{~A}$ ), and from -2.9 to $+7.6 \mathrm{~g} \mathrm{~N} \cdot \mathrm{m}^{-2} \cdot$ year $^{-1}$ or $-47 \%$ to $+82 \%$, under the GFDL A1FI scenario (Fig. $8 \mathrm{~B}$ ). Under both climate scenarios, the largest increases in net $\mathrm{N}$ mineralization occurred in 
Fig. 7. Change in runoff in $\mathrm{cm} \cdot \mathrm{year}^{-1}$ from 1971-2000 to 2070-2099 across the northern Great Lakes region of the United States under two climate scenarios (PCM B1 and GFDL A1FI) with and without the $\mathrm{CO}_{2}$ routine implemented in PnET-CN. Figure 7 is available in color online.
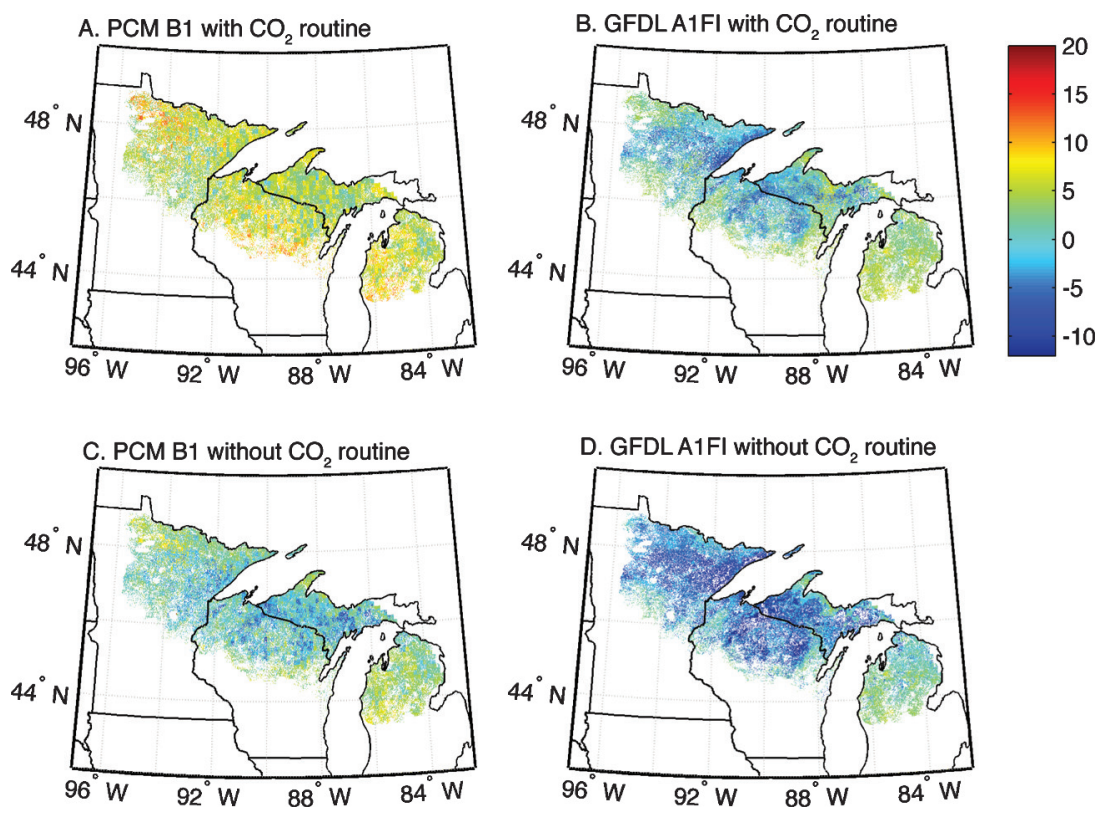

Fig. 8. Change in net nitrogen $(\mathrm{N})$ mineralization in $\mathrm{g} \mathrm{N} \cdot \mathrm{m}^{-2} \cdot$ year $^{-1}$ from 1971-2000 to 2070-2099 across the northern Great Lakes region of the United States under two climate scenarios (PCM B1 and GFDL A1FI) with and without the $\mathrm{CO}_{2}$ routine implemented in PnET-CN. Figure 8 is available in color online.
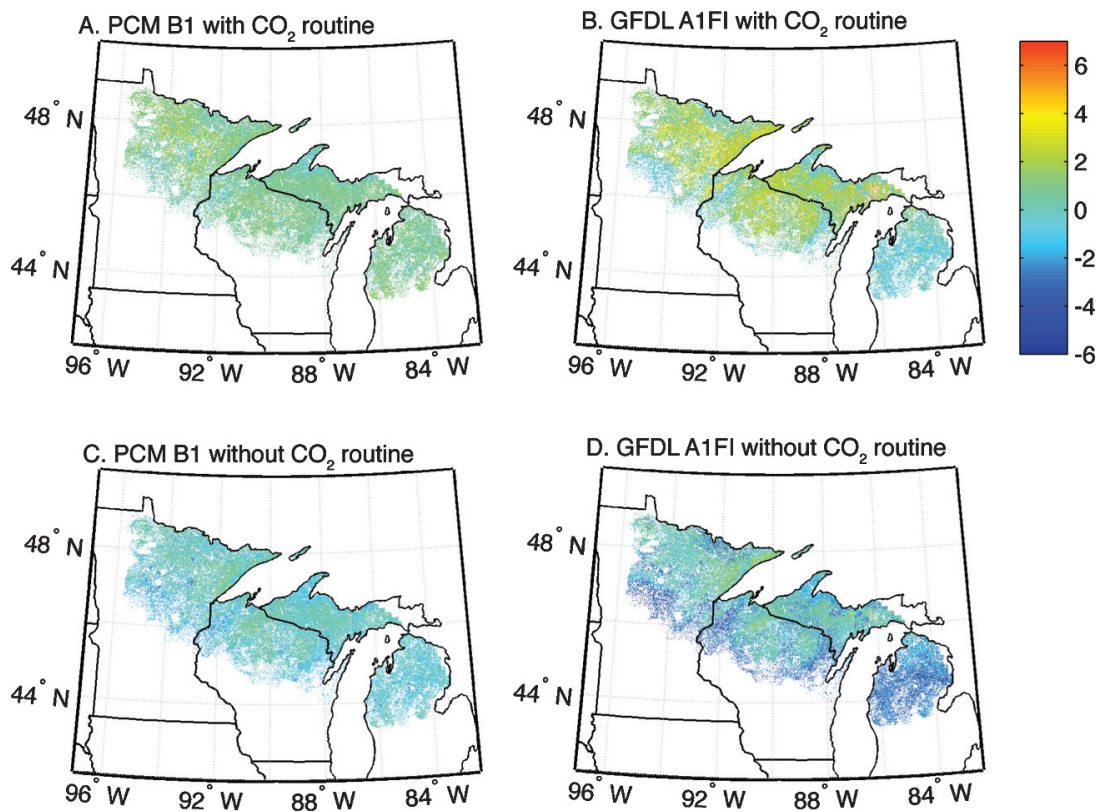

north-central and northeastern Minnesota, northern Wisconsin, and upper Michigan.

Changes in net $\mathrm{N}$ mineralization also varied with forest type. The largest average regional increases in net $\mathrm{N}$ mineralization with the $\mathrm{CO}_{2}$ routine implemented occurred in spruce-fir forests, whereas oak-hickory and aspen-birch forests showed the smallest average regional increases in net $\mathrm{N}$ mineralization (Table 2).

\section{Discussion}

Under two potential future climate and atmospheric $\mathrm{CO}_{2}$ scenarios (selected to bookend a range of climate predictions), PnET-CN predicted a wide variety of impacts on forest ecosystem processes in the Great Lakes region of North America, with im-

pacts varying geographically within the region. Depending on the climate scenario (but including rising $\mathrm{CO}_{2}$ ), our results suggest average regional aboveground net primary productivity could increase from $67 \%$ to $142 \%$, changes in evapotranspiration could range from $-3 \%$ to $+6 \%$, runoff could increase from $2 \%$ to $22 \%$, and net $\mathrm{N}$ mineralization could increase from $10 \%$ to $12 \%$. Using PnET-CN at five sites in northeastern USA with similar forest types to our study region, Ollinger et al. (2008) found net primary productivity increased by $25 \%-88 \%$ and runoff changed by $-2 \%$ to $+53 \%$ on average under four future climate scenarios (PCM and HadCM3 general circulation models with $\mathrm{B} 1$ and A1 emission scenarios). Using the detailed hydrological model VIC, Cherkauer and Sinha (2010) predicted changes in annual evapotranspiration 
of $\pm 7 \%$ across the Lake Michigan region under six climate scenarios (GFDL and HadCM3 general circulation models with B1, A2, and A1B emission scenarios), with Wisconsin and Michigan generally showing small increases in evapotranspiration. In addition, Cherkauer and Sinha (2010) found annual runoff increased on average by $10 \%$ across the Lake Michigan region. It is important to note that $\mathrm{CO}_{2}$ effects on stomatal conductance, however, were not accounted for in this hydrological model.

We found that predicted impacts to forest ecosystem processes were generally influenced more by potential changes in $\mathrm{CO}_{2}$ than by potential changes in temperature or precipitation; moreover, that climate change effects were also quite dependent on $\mathrm{CO}_{2}$ levels. More specifically, the predicted increases in productivity when the $\mathrm{CO}_{2}$ routine was implemented could largely be attributed to the indirect effect of rising $\mathrm{CO}_{2}$ on reduced water stress and, hence, higher photosynthetic rates. In the PnET-CN model, direct $\mathrm{CO}_{2}$ effects on photosynthesis are represented as a saturating response, whereas indirect effects via reduced stomatal conductance and water stress do not acclimate with increasing $\mathrm{CO}_{2}$ concentrations. While PnET-CN tends to predict a larger $\mathrm{CO}_{2}$ fertilization effect on productivity than other ecosystem models (Medlyn et al. 2011), it is difficult to assess whether our predicted increases are unreasonably high because no field studies have yet examined ecosystem responses to $\mathrm{CO}_{2}$ concentrations $>700 \mathrm{ppm}$ in mature forests. Until the mechanisms are more clearly understood for how $\mathrm{CO}_{2}$ concentrations affect ecosystem $\mathrm{C}$ dynamics, modifying the algorithms of the PnET-CN $\mathrm{CO}_{2}$ routine to more accurately simulate the effects of $\mathrm{CO}_{2}$ on forest ecosystem processes remains a challenge.

Despite the predicted strong average increase in productivity under both climate scenarios, there was a remarkable range of responses depending on geography, climate, and forest type. However, even with the wide range in predicted productivity, the most important spatial drivers of this variation were relatively consistent among future climate scenarios and suggest the productivity of Great Lakes forests switch from being temperatureto water-limited by the end of the century. These findings are consistent with other studies that show cold temperate and boreal forests are currently temperature-limited (Hyvonen et al. 2007; Gough et al. 2008; Reich and Oleksyn 2008; Bradford 2011; Dieleman et al. 2012; Fisichelli et al. 2012). We found, however, that predicted temperature increases under the warmest climate scenario (GFDL A1FI) exceeded forest-type-specific temperature thresholds and increased vapor pressure deficits enough to shift current Great Lakes forest systems to being water-limited by 2099. For all forest types under the GFDL A1FI scenario with the $\mathrm{CO}_{2}$ routine implemented, future productivity was negatively correlated with temperature across the region (Supplementary data Table 5). ${ }^{1}$ Soils also played a critical role in determining the vulnerability and potential of forests to respond positively or negatively to projected climate changes. Specifically, areas with lower water-holding capacity were less buffered from water limitation and more prone to reductions or smaller increases in productivity. The suggestion that plant-soil-water relations will become an increasingly important control over forest productivity in the region implies that regional monitoring efforts should explicitly include a range of soil conditions for each forest type.

Although ecosystem responses to future climate scenarios varied by forest type in this study, we found relatively small differences among the four deciduous forest types (aspen-birch, maple-beech-birch, elm-ash-cottonwood, and oak-hickory). This is not surprising given that the main difference in how these forest types were parameterized in PnET-CN was the leaf mass per area parameter. Also, all deciduous and pine forest types were parameterized using the same minimum $\left(4^{\circ} \mathrm{C}\right)$ and optimum $\left(24^{\circ} \mathrm{C}\right)$ temperature parameters for photosynthesis (Aber and Driscoll 1997; Aber et al. 1997). These temperature thresholds likely vary within and among species composing these forest types, although preliminary analyses from studies of 10 Great Lakes species did not find interspecific differences (P.B. Reich, unpublished data); however, there are insufficient studies at present to allow for changing these values to represent Great Lakes forest types.

When interpreting the results from this study, it is important to consider several additional sources of uncertainty and limitations of the PnET-CN model. First, spatial processes, such as succession, migration, and natural disturbances, are not accounted for in the model. Interactions between climate change, fragmentation, dispersal, and competition will likely play an important role in influencing the future composition and structure and, hence, function of Great Lakes forests (Scheller and Mladenoff 2008). Second, PnET-CN does not account for climate-sensitive stages of plant regeneration, such as germination and seedling establishment (Price et al. 2001; De Frenne et al. 2012; Fisichelli et al. 2012; Walker et al. 2012). Third, although it is possible to account for land-use history in PnET-CN, we did not include disturbance events (harvest, fire, windthrow, and insect or disease defoliation) in this study because trends in disturbance intensity and frequency are difficult to predict (Flannigan et al. 2009) and previous work shows disturbance is a relatively less important control on long-term forest productivity in the Great Lakes region than climate, soil, or species traits (Peters et al. 2012). Results from this study, therefore, should be regarded as "best case" or potential ecosystem responses to future changes in climate and $\mathrm{CO}_{2}$. Fourth, major uncertainties remain about future greenhouse gas emissions, $\mathrm{N}$ deposition rates, and tropospheric ozone concentrations. While we held future $\mathrm{N}$ deposition rates and ozone concentrations equal to current values, it is possible these values could rise or decline over time, depending on complex interactions between emissions, atmospheric composition, and climate (Galloway et al. 2004; Vingarzan 2004; Racherla and Adams 2006; Sitch et al. 2007). We purposely chose to examine the effects of both a plausible rising and an unrealistic low, stable $\mathrm{CO}_{2}$ emissions scenario to help interpret the role of rising $\mathrm{CO}_{2}$ in future forest processes; however, it is possible future emissions will exceed the A1FI emissions projection (our most plausible scenario). Indeed, future emissions projections that exceed A1FI are currently being considered by the Intergovernmental Panel on Climate Change in its fifth assessment report (http://www.ipcc.ch/; 10 December 2012).

\section{Conclusion}

This model application study evaluates the long-term effects of two potential climate change scenarios on forest ecosystem processes, particularly productivity, evapotranspiration, runoff, and net $\mathrm{N}$ mineralization, across the Great Lakes region of North America. When the $\mathrm{CO}_{2}$ routine was included (rising $\mathrm{CO}_{2}$ ), our results suggest that, depending on the climate scenario, average regional changes in productivity could increase from $67 \%$ to $142 \%$, changes in evapotranspiration could range from $-3 \%$ to $6 \%$, runoff could increase from $2 \%$ to $22 \%$, and net $\mathrm{N}$ mineralization could increase $10 \%$ to $12 \%$. When the $\mathrm{CO}_{2}$ routine was excluded (constant $\mathrm{CO}_{2}$ ), productivity was either stable or decreased, suggesting that increases in productivity were the consequence of the rising $\mathrm{CO}_{2}$ itself, not the changing climate. Ecosystem responses varied geographically with the largest increases in productivity and net $\mathrm{N}$ mineralization in northeastern Minnesota, northern Wisconsin, and upper Michigan, and the largest increases in evapotranspiration and runoff in lower Michigan. Ecosystem responses also varied by forest type, with deciduous forest types (aspen-birch, maple-beech-birch, elm-ash-cottonwood, and oak-hickory) showing the largest increases in productivity, followed by pine and spruce-fir forests. Despite the wide range in predicted productivity, the most important spatial drivers of this variation were relatively consistent among future climate scenarios and suggest the productivity of Great Lakes forests will switch from being temperature-limited to water-limited by the end of the century. 
Impacts of climate scenarios were strongly sensitive to the effects of $\mathrm{CO}_{2}$, particularly through reduced stomatal conductance and water stress, supporting the idea that interactions between simultaneously changing environmental factors can be complex and antagonistic. This work identifies a range of potential forest ecosystem responses to climate change in the Great Lakes region while highlighting geographical differences in these responses that will be useful for natural resource planning and management.

\section{Acknowledgements}

We thank Scott Ollinger for advice on the PnET-CN model, Matthew Peters for sharing soil water-holding capacity data, and the Northern Institute of Applied Climate Science for climate data and extensive discussions about the implications of this work for forest managers. This work contributed to a larger coordinated effort involving several modeling teams to assess the vulnerability of Great Lakes forests to climate change (www.climateframe work.org; 29 November 2012). This research was funded by the University of Minnesota's Institute on the Environment, the Wilderness Research Foundation, and the Superior National Forest. Any use of trade, product, or firm names is for descriptive purposes only and does not imply endorsement by the US Government.

\section{References}

Aber, J.D., and Driscoll, C.T. 1997. Effects of land use, climate variation, and $\mathrm{N}$ deposition on N cycling and C storage in northern hardwood forests. Glob. Biogeochem. Cycles, 11: 639-648. doi:10.1029/97GB01366.

Aber, J.D., Ollinger, S.V., Federer, C.A., Reich, P.B., Goulden, M.L., Kicklighter, D.W., Melillo, J.M., and Lathrop, R.G. 1995. Predicting the effects of climate change on water yield and forest production in the northeastern United States. Clim. Res. 5: 207-222. doi:10.3354/cr005207.

Aber, J.D., Reich, P.B., and Goulden, M.L. 1996. Extrapolating leaf CO exchange to the canopy: a generalized model of forest photosynthesis compared with measurements by eddy correlation. Oecologia, 106: 257-265. doi:10.1007| BF00328606.

Aber, J.D., Ollinger, S.V., and Driscoll, C.T. 1997. Modeling nitrogen saturation in forest ecosystems in response to land use and atmospheric deposition. Ecol. Model. 101: 61-78. doi:10.1016/S0304-3800(97)01953-4.

Aber, J.D., Ollinger, S.V., Driscoll, C.T., Likens, G.E., Holmes, R.T., Freuder, R.J., and Goodale, C.L. 2002. Inorganic nitrogen losses from a forested ecosystem in response to physical, chemical, biotic, and climatic perturbations. Ecosystems, 5: 648-658. doi:10.1007/s10021-002-0203-8.

Aerts, R., Cornelissen, J.H.C., and Dorrepaal, E. 2006. Plant performance in a warmer world: general responses of plants from cold, northern biomes and the importance of winter and spring events. Plant Ecol. 182: 65-77. doi:10. 1007/s11258-005-9031-1.

Bailey, R.G. 1995. Description of the ecoregions of the United States. USDA Forest Service, Washington, D.C. Publication No. 1391.

Bradford, J.B. 2011. Divergence in forest-type response to climate and weather: evidence for regional links between forest-type evenness and net primary productivity. Ecosystems, 14: 975-986. doi:10.1007/s10021-011-9460-8.

Cherkauer, K.A., and Sinha, T. 2010. Hydrologic impacts of projected future climate change in the Lake Michigan region. J. Great Lakes Res. 36: 33-50. doi:10.1016/j.jglr.2009.11.012.

De Frenne, P., Graae, B.J., Brunet, J., Shevtsova, A., De Schrijver, A., Chabrerie, O., Cousins, S.A.O., Decocq, G., Diekmann, M., Hermy, M., Heinken, T., Kolb, A., Nilsson, C., Stanton, S., and Verheyen, K. 2012. The response of forest plant regeneration to temperature variation along a latitudinal gradient. Ann. Bot. 109: 1037-1046. doi:10.1093/aob/mcs015. PMID:22345113.

Dieleman, W.I.J., Vicca, S., Dijkstra, F.A., Hagedorn, F., Hovenden, M.J., Larsen, K.S., Morgan, J.A., Volder, A., Beier, C., Dukes, J.S., King, J., Leuzinger, S., Linder, S., Luo, Y., Oren, R., De Angelis, P., Tingey, D., Hoosbeek, M.R., and Janssens, I.A. 2012. Simple additive effects are rare: a quantitative review of plant biomass and soil process responses to combined manipulations of $\mathrm{CO}_{2}$ and temperature. Glob. Chang. Biol. 18: 2681-2696. doi:10.1111/j.1365-2486.2012.02745.x.

Ellsworth, D.S., and Reich, P.B. 1993. Canopy structure and vertical patterns of photosynthesis and related leaf traits in a deciduous forest. Oecologia, 96: 169-178. doi:10.1007/BF00317729.

Fisichelli, N., Frelich, L.E., and Reich, P.B. 2012. Sapling growth responses to warmer temperatures "cooled" by browse pressure. Glob. Chang. Biol. 18: 3455-3463. doi:10.1111/j.1365-2486.2012.02785.x.

Flannigan, M.D., Krawchuk, M.A., de Groot, W.J., Wotton, B.M., and Gowman, L.M. 2009. Implications of changing climate for global wildland fire. Int. J. Wildland Fire, 18: 483-507. doi:10.1071/WF08187.
Frelich, L.E., and Reich, P.B. 2010. Will environmental changes reinforce the impact of global warming on the prairie-forest border of central North America? Front. Ecol. Environ. 8: 371-378. doi:10.1890/080191.

Galatowitsch, S., Frelich, L., and Phillips-Mao, L. 2009. Regional climate change adaptation strategies for biodiversity conservation in a midcontinental region of North America. Biol. Conserv. 142: 2012-2022. doi:10.1016/j.biocon. 2009.03.030.

Galloway, J.N., Dentener, F.J., Capone, D.G., Boyer, E.W., Howarth, R.W., Seitzinger, S.P., Asner, G.P., Cleveland, C.C., Green, P.A., Holland, E.A., Karl, D.M., Michaels, A.F., Porter, J.H., Townsend, A.R., and Vorosmarty, C.J. 2004. Nitrogen cycles: past, present, and future. Biogeochemistry, 70: 153226. doi:10.1007/s10533-004-0370-0.

Gough, C.M., Vogel, C.S., Schmid, H.P., and Curtis, P.S. 2008. Controls on annual forest carbon storage: Lessons from the past and predictions for the future. Bioscience, 58: 609-622. doi:10.1641/B580708.

Gunderson, C.A., Norby, R.J., and Wullschleger, S.D. 2000. Acclimation of photosynthesis and respiration to simulated climatic warming in northern and southern populations of Acer saccharum: laboratory and field evidence. Tree Physiol. 20: 87-96. doi:10.1093/treephys/20.2.87. PMID:12651476.

Hansen, J., Sato, M., and Ruedy, R. 2012. Perception of climate change. Proc. Natl. Acad. Sci. U.S.A. 109: E2415-E2423. doi:10.1073/pnas.1205276109. PMID: 22869707.

Hyvonen, R., Agren, G.I., Linder, S., Persson, T., Cotrufo, M.F., Ekblad, A., Freeman, M., Grelle, A., Janssens, I.A., Jarvis, P.G., Kellomaki, S., Lindroth, A., Loustau, D., Lundmark, T., Norby, R.J., Oren, R., Pilegaard, K., Ryan, M.G., Sigurdsson, B.D., Stromgren, M., van Marcel, O., and Wallin, G. 2007. The likely impact of elevated $\left[\mathrm{CO}_{2}\right]$, nitrogen deposition, increased temperature and management on carbon sequestration in temperate and boreal forest ecosystems: a literature review. New Phytologist, 173: 463-480. doi:10.1111/j. 1469-8137.2007.01967.x. PMID:17244042.

Kallarackal, J., and Roby, T.J. 2012. Responses of trees to elevated carbon dioxide and climate change. Biodivers. Conserv. 21: 1327-1342. doi:10.1007/s10531-0120254-X.

Karl, T.R., Melilo, J.M., and Peterson, T.C. (Editors). 2009. Global climate change impacts in the United States. Cambridge University Press, New York.

Liepert, B.G. 2002. Observed reductions of surface solar radiation at sites in the United States and worldwide from 1961 to 1990. Geophys. Res. Lett. 29: 14211425. doi:10.1029/2002GL014910.

Lindquist, E.J., D’Annunzio, R., Gerrand, A., MacDicken, K., Achard, F., Beuchle, R., Brink, A., Eva, H.D., Mayaux, P., San-Miguel-Ayanz, J., and Stibig, H.-J. 2012. Global forest land-use change 1990-2005. Food and Agriculture Organization of the United Nations and European Commission Joint Research Centre, Rome. FAO Forestry Paper No. 169.

McNeil, B.E., Martell, R.E., and Read, J.M. 2006. GIS and biogeochemical models for examining the legacy of forest disturbance in the Adirondack Park, NY, U.S.A. Ecol. Model. 195: 281-295. doi:10.1016/j.ecolmodel.2005.11.028.

Medlyn, B.E., Barton, C.V.M., Broadmeadow, M.S.J., Ceulemans, R., De Angelis, P., Forstreuter, M., Freeman, M., Jackson, S.B., Kellomaki, S., Laitat, E., Rey, A., Roberntz, P., Sigurdsson, B.D., Strassemeyer, J., Wang, K., Curtis, P.S., and Jarvis, P.G. 2001. Stomatal conductance of forest species after long-term exposure to elevated $\mathrm{CO}_{2}$ concentration: a synthesis. New Phytol. 149: 247-264. doi:10.1046/j.1469-8137.2001.00028.x.

Medlyn, B.E., Duursma, R.A., and Zeppel, M.J.B. 2011. Forest productivity under climate change: a checklist for evaluating model studies. Wiley Interdisciplinary Rev.: Climate Change, 2: 332-355. doi:10.1002/wcc.108.

Norby, R.J., and Zak, D.R. 2011. Ecological lessons from Free-Air $\mathrm{CO}_{2}$ Enrichment (FACE) Experiments. Annu. Rev. Ecol. Evol. Syst. 42: 181-203. doi:10.1146/ annurev-ecolsys-102209-144647.

Norby, R.J., Warren, J.M., Iversen, C.M., Medlyn, B.E., and McMurtrie, R.E. 2010. $\mathrm{CO}_{2}$ enhancement of forest productivity constrained by limited nitrogen availability. Proc. Natl. Acad. Sci. U.S.A. 107: 19368-19373. doi:10.1073/pnas. 1006463107. PMID:20974944.

Ollinger, S.V., Aber, J.D., and Federer, C.A. 1998. Estimating regional forest productivity and water yield using an ecosystem model linked to a GIS. Landsc. Ecol. 13: 323-334. doi:10.1023/A:1008004423783.

Ollinger, S.V., Aber, J.D., Reich, P.B., and Freuder, R.J. 2002. Interactive effects of nitrogen deposition, tropospheric ozone, elevated $\mathrm{CO}_{2}$ and land use history on the carbon dynamics of northern hardwood forests. Glob. Chang. Biol. 8: 545-562. doi:10.1046/j.1365-2486.2002.00482.x.

Ollinger, S.V., Goodale, C.L., Hayhoe, K., and Jenkins, J.P. 2008. Potential effects of climate change and rising $\mathrm{CO}_{2}$ on ecosystem processes in northeastern $\mathrm{U}$. S. forests. Mitigat. Adapt. Strategies Glob. Change, 13: 467-486. doi:10.1007/ s11027-007-9128-z.

Pan, Y.D., Birdsey, R., Hom, J., and McCullough, K. 2009. Separating effects of changes in atmospheric composition, climate and land-use on carbon sequestration of US Mid-Atlantic temperate forests. For. Ecol. Manage. 259: 151-164. doi:10.1016/j.foreco.2009.09.049.

Peters, E.B., Wythers, K.R., Bradford, J.B., and Reich, P.B. 2013. Influence of disturbance on temperate forest productivity. Ecosystems, 16(1): 95-110. doi: 10.1007/s10021-012-9599-y.

Price, D.T., Zimmermann, N.E., van der Meer, P.J., Lexer, M.J., Leadley, P., Jorritsma, I.T.M., Schaber, J., Clark, D.F., Lasch, P., McNulty, S., Wu, J.G., and Smith, B. 2001. Regeneration in gap models: Priority issues for studying forest 
responses to climate change. Climatic Change, 51: 475-508. doi:10.1023/A: 1012579107129.

Racherla, P.N., and Adams, P.J. 2006. Sensitivity of global tropospheric ozone and fine particulate matter concentrations to climate change. J. Geophys. Res. 111: D24103. doi:10.1029/2005JD006939.

Ravenscroft, C., Scheller, R.M., Mladenoff, D.J., and White, M.A. 2010. Forest restoration in a mixed-ownership landscape under climate change. Ecol. Appl. 20: 327-346. doi:10.1890/08-1698.1. PMID:20405791.

Reich, P.B., and Oleksyn, J. 2008. Climate warming will reduce growth and survival of Scots pine except in the far north. Ecol. Lett. 11: 588-597. doi:10. 1111/j.1461-0248.2008.01172.x. PMID:18363717.

Reich, P.B., Ellsworth, D.S., and Walters, M.B. 1998. Leaf structure (specific leaf area) modulates photosynthesis-nitrogen relations: evidence from within and across species and functional groups. Funct. Ecol. 12: 948-958. doi:10. 1046/j.1365-2435.1998.00274.x.

Scheller, R.M., and Mladenoff, D.J. 2008. Simulated effects of climate change, fragmentation, and inter-specific competition on tree species migration in northern Wisconsin, U.S.A. Clim. Res. 36: 191-202. doi:10.3354/cr00745.

Sitch, S., Cox, P.M., Collins, W.J., and Huntingford, C. 2007. Indirect radiative forcing of climate change through ozone effects on the land-carbon sink. Nature, 448: 791-796. doi:10.1038/nature06059. PMID:17653194.

Solomon, S., Qin, D., Manning, M., Chen, Z., Marquis, M., Averyt, K.B., Tignor, M. and Miller, H.L. (Editors). 2007. Climate Change 2007: The Physical Science
Basis. Contribution of Working Group I to the Fourth Assessment Report of the Intergovernmental Panel on Climate Change. Cambridge University Press, Cambridge, UK.

Stoner, A.M.K., Hayhoe, K., Yang, X., and Wuebbles, D.J. 2012. An asynchronous regional regression model for statistical downscaling of daily climate variables. Int. J. Climatol. 33(11): 2473-2494. doi:10.1002/joc.3603.

Taylor, P.C. 2012. The role of clouds: an introduction and rapporteur report. Surv. Geophys. 33: 609-617. doi:10.1007/s10712-012-9182-2.

Vingarzan, R. 2004. A review of surface ozone background levels and trends. Atmos. Environ. 38: 3431-3442. doi:10.1016/j.atmosenv.2004.03.030.

Walker, X., Henry, G.H.R., McLeod, K., and Hofgaard, A. 2012. Reproduction and seedling establishment of Picea glauca across the northernmost foresttundra region in Canada. Glob. Chang. Biol. 18: 3202-3211. doi:10.1111/j.13652486.2012.02769.x.

Wilson, B.T., Lister, A.J., and Riemann, R.I. 2012. A nearest-neighbor imputation approach to mapping tree species over large areas using forest inventory plots and moderate resolution raster data. For. Ecol. Manage. 271: 182-198. doi:10.1016/j.foreco.2012.02.002.

Wythers, K.R., Reich, P.B., and Bradford, J.B. 2013. Incorporating temperaturesensitive Q10 and foliar respiration acclimation algorithms modify modeled ecosystem responses to global change. J. Geophys. Res. Biogeosci. 118: 1-14. doi:10.1029/2011JG001897. 
Copyright of Canadian Journal of Forest Research is the property of Canadian Science Publishing and its content may not be copied or emailed to multiple sites or posted to a listserv without the copyright holder's express written permission. However, users may print, download, or email articles for individual use. 